IZA DP No. 6684

Sexual Orientation Discrimination in the Cypriot Labour Market: Distastes or Uncertainty?

Nick Drydakis

June 2012 


\title{
Sexual Orientation Discrimination in the Cypriot Labour Market: Distastes or Uncertainty?
}

\author{
Nick Drydakis \\ University of Patras, \\ Scientific Centre for the Study of Discrimination, Athens \\ and IZA
}
Discussion Paper No. 6684
June 2012

IZA
P.O. Box 7240
53072 Bonn
Germany

Phone: +49-228-3894-0

Fax: +49-228-3894-180

E-mail: iza@iza.org

\begin{abstract}
Any opinions expressed here are those of the author(s) and not those of IZA. Research published in this series may include views on policy, but the institute itself takes no institutional policy positions.

The Institute for the Study of Labor (IZA) in Bonn is a local and virtual international research center and a place of communication between science, politics and business. IZA is an independent nonprofit organization supported by Deutsche Post Foundation. The center is associated with the University of Bonn and offers a stimulating research environment through its international network, workshops and conferences, data service, project support, research visits and doctoral program. IZA engages in (i) original and internationally competitive research in all fields of labor economics, (ii) development of policy concepts, and (iii) dissemination of research results and concepts to the interested public.
\end{abstract}

IZA Discussion Papers often represent preliminary work and are circulated to encourage discussion. Citation of such a paper should account for its provisional character. A revised version may be available directly from the author. 


\title{
ABSTRACT \\ Sexual Orientation Discrimination in the Cypriot Labour Market: Distastes or Uncertainty?
}

\begin{abstract}
Sexual orientation and employment bias is examined in Cyprus (Republic of Cyprus: Nicosia, Limassol, Larnaca, Paphos) by implementing an experiment for the period 2010-2011. The design is aimed at answering three main questions: Do gay and lesbian people face occupational access constraints and entry wage bias than comparable heterosexuals? Do gay and lesbian people benefit from providing more job-related information? Does the differential treatment between gay/lesbian and heterosexual applicants disappear as the information of the applicants increases? Methodologically, we sent applications to advertised vacancies and we experimented with two information sets the 'sexual orientation' and 'information' of the potential applicants. The estimations suggest that gay and lesbian applicants face significant bias than heterosexual applicants. Moreover, both heterosexual and gay/lesbian applicants gain by providing more job-related information. However, the estimations suggest that the informational premium for sexual orientation minorities could not reduce the discriminatory patterns. The current results indicate that discrimination against sexual orientation minorities in the Cypriot labour market is a matter of preference, not the result of limited information. One strategy the Cypriot government may employ is to try to affect public opinion and people's attitudes towards sexual orientation minorities. This is the first nationwide field experiment in the Cypriot labour market and contributes to the literature as it is the first field study on sexual orientation which tries to disentangle statistical from taste-based discrimination in the labour market.
\end{abstract}

JEL Classification: $\quad \mathrm{C} 93, \mathrm{~J} 7, \mathrm{~J} 82$

Keywords: sexual orientation, hiring discrimination, entry wage offers, taste theory of discrimination, statistical theory of discrimination

Corresponding author:

Nick Drydakis

Department of Economics

University of Patras

University Campus

26504 Rio

Greece

E-mail: ndrydakis@econ.soc.uoc.gr 


\section{Introduction}

Economists suggest that labour market discrimination takes place because employers dislike minorities or/and because employers assume that minority employees are less skilled and profitable as employees than the general population (Becker 1957; Phelps, 1972; Arrow, 1973; Becker 1993; Arrow 1998; Baumle and Fossett, 2005; Brue et al., 2006; Charles and Guryan, 2008). In the current study, we are interested in examining the employment of gay males and lesbians in Cyprus. Unfortunately, in Cyprus no data samples include the sexual orientation of individuals which precludes an investigation of this discrimination hypothesis. The current study, assesses differential treatment of sexual orientation minorities using an established experimental technique; the so-called Correspondence Test (Riach and Rich, 2002). The goal is to produce pairs of applicants who submit a written job application to the same firm. These fictitious applicants should be identical in all relevant characteristics so that any systematic difference in treatment within a pair can only be attributed to the effects of sexual orientation. In the current study, following Adam (1981), Weichselbaumer (2003), Drydakis (2009; 2011), Tilcsik (2011) and Ahmed et al. (2012) a gay male /lesbian applicant's sexual orientation was disclosed through a reference in his/her curriculum vitae to work as a volunteer for a gay association. Since discrimination theories are only valid if the employer believes that the employee is a gay male/lesbian, this study focuses on a group of people likely to be viewed as gay male/lesbian (Drydakis, 2009; 2011).

In this study, we firstly examine whether gay male and lesbian applicants face occupational access constraints and entry wage bias than comparable heterosexuals. More importantly, in the current study we contribute to the literature by examining how 
increasing job-related information should affect sexual orientation bias in the labour market. We hypothesize that adding favourable job-related information to the applications should reduce occupational access and wage difference between sexual orientation minorities and majorities (Feltovich and Papageorgiou, 2004; Lahey, 2008; Kaas and Manger, 2011). Indeed, economic models of statistical discrimination emphasize the cognitive utility of group estimates as a means of dealing with the problems of low information and uncertainty (Arrow 1973; 1998; Altonji, and Pierret, 2001; Van Hoye and Lievens, 2003). This study is the first field experiment on sexual orientation which aims to disentangle statistical from taste-based discrimination in the labour market. Thus, the scope of this study is to explain real-world social issues and to provide knowledge and insight that is relevant for improving our understanding of the world and to help solve the problems faced by sexual orientation minorities.

The study is organized as follows. Section 2 presents an overview of gay male and lesbian issues in Cyprus. Section 3 provides a review of the existing literature on field experiments of discrimination. Section 4 describes the methodology in detail. Section 5 presents the descriptive statistics, and Section 6 presents the estimations followed by a discussion.

\section{Sexual orientation issues in Cyprus}

The population of Cyprus is ethnically and geographically divided between the majority Greek speakers in the South Cypriot Cities (Republic of Cyprus: Nicosia, Limassol, Larnaca, Paphos) and the Turkish speakers in the occupied North Cypriot Cities (Nicosia, Kyrenia, Famagusta). Cyprus currently boasts the only divided capital in Europe with the United Nations Green Line running from East to West across the 
country, and dividing Nicosia (the capital) in the process. Although the European Union aims to integrate its entire membership into a new model of active citizenship within the context of diversity, sexual orientation minorities in Cyprus are at a disadvantage. According to the European Union Agency for Fundamental Rights (European Union Agency for Fundamental Rights FRA, 2008) prejudices amongst society and the lack of targeted awareness raising measures have so far prevented gay males and lesbians from using the equality body procedure (Council Directive 2000/78/EC) at national level.

The scarce qualitative surveys show that homophobia and discrimination against gay male and lesbian people is widespread, and the issue of homosexuality is a taboo subject in the South Cypriot Cities (European Union Agency for Fundamental Rights FRA, 2008; 2009). Eurobarometer surveys (2006; 2007) estimate that Southern Cyprus is the most puritanical society in the European Union in terms of general attitudes toward homosexuality. Eurobarometer (2007) reveals that a large majority of Cypriots (86\%) feel that homosexuality is a taboo, compared to $48 \%$ of European Union respondents. Moreover, Eurobarometer (2006) shows that $14 \%$ of Cypriots feel that same sex marriage should be allowed, compared to $44 \%$ of European Union respondents. In fact, Onoufriou (2009) evaluates that gay male and lesbian people in Greek-Cyprus are viewed as a threat to national and orthodox tradition. Where gay male and lesbian people do not succeed in the roles assumed for them they are viewed as outcasts who have let the family, and even Cyprus, down in some way (Onoufriou, 2009).

It is increasingly important, given the legal actions in Cyprus that have the potential to affect sexual orientation minorities to understand the relationship and the underlying mechanisms between sexual orientation and employment. It is crucial to 
have employment data for sexual orientation minorities for current evaluations and future comparisons in order to assert gay male and lesbian rights for better working conditions and to mobilize people around the rights of sexual orientation minorities. Provided that identifying the sources of sexual orientation differences (i.e. distastes or uncertainty against minorities) in employment is crucial in implementing effective policy decisions so as to reduce them (Neumark, 1999). Field experiments on discrimination have become particularly relevant in view of the European Union's decision in its Employment Equality Directive to require member states to extend legislation ensuring equality of opportunity, including sexual orientation-based labour discrimination (Makkonen, 2007). Such a potential of directly collecting discrimination data may in turn further support antidiscrimination policies (Makkonen, 2007).

\section{Field experiments of discrimination in the labour market}

The correspondence test involves sending carefully matched pairs of written job applications in response to advertised vacancies to test for hiring discrimination in labour at the initial stage of interview selection (Riach and Rich, 2002). The applicants are typically matched on attributes such as age, education, experiences and marital status. Employers' reactions are typically measured by written responses or callbacks. Different forms of field experiments have been used to test for discrimination in hiring. A number of these studies have documented a significant relationship between ethnicity (Jowell and Prescott-Clarke, 1970; Bertrand and Mullainathan, 2004), gender (Neumark, et al. 1996; Weichselbaumer, 2004) and labour market outcomes.

Adam (1981) conducted a field experiment to test discrimination based on sexual orientation and found a reduction of $10 \%$ in job offer rates for gay male and 
lesbian applicants in Toronto, Canada. Weichselbaumer (2003) used a similar technique to investigate whether the Austrian labour market discriminated against lesbians. She found that the indication of a lesbian identity reduced the offer rate by $12-13 \%$. Moreover, Drydakis (2009) led to the observation that gay males faced lower access to occupations $(26 \%)$ and lower initial wage offers (1.5\%) from employers in Greece. In addition, Drydakis (2011) found that lesbians face lower occupational access (27\%) and are offered lower entry wages $(6 \%)$ than their heterosexual counterparts in Greece. Furthermore, Tilcsik (2011) estimated that openly gay male applicants faced significant discrimination in the US labour market. Finally, Ahmed et al., (2012) found that gay males faced lower access to occupations (3-6\%), as well as, lesbians faced occupational access constraints $(6 \%)$ in Sweden ${ }^{1}$. The findings of these Correspondence Tests are consistent with the notion that a majority of the population has a tendency to discriminate, motivating employers to discriminate against both gay males and lesbians (Becker, 1957; 1993). Importantly, however, discrimination can also occur if employers use group information when evaluating applicants (Arrow, 1973; 1998).

In brief, the distaste hypothesis (Becker, 1957; 1993) describes discrimination as a preference or taste for which the discriminator is willing to pay. The taste for discrimination by employers is based on the idea that they want to maintain a physical

\footnotetext{
${ }^{1}$ Furthermore, Ahmed et al. (2008) and Ahmed and Hammarstedt (2009) using various Correspondent Tests found no indication of differential treatment of lesbians, but they found discrimination against gay males in the Swedish housing market. Similarly, Lauster and Easterbrook (2011) using a Correspondent Test found housing discriminated against gay males in Canada. Note also that, Hebl et al. (2002) using a sexual orientation Audit in Texas labour marker found various interesting patterns.
} 
or social distance from certain groups or that they fear that their customers or coworkers dislike transacting with minorities. Becker suggests that discrimination coefficients incorporate the influence of characteristics unrelated to productivity, such as tastes and attitudes towards gay male and lesbian people (England, 1994; Jaret, 1995). Following the taste theory, employers may offer gay males and lesbians a lower wage compared to the heterosexuals in order to equalize the unit cost of labour once psychic costs are factored in. However, if the distaste for the gay male and lesbian population is high enough, employers will prefer not to employ then in their firms. Charles and Guryan (2008) test for, and confirm, a series of key predictions from the standard Becker model in the US labour market. So long as employers' prejudices persist, the size of the penalty will be directly related to the strength of the employer's prejudice, and discrimination will be practiced consistently against the minorities by prejudiced agents ${ }^{2}$.

In addition, statistical discrimination (Phelps, 1972; Arrow, 1973; 1998) predicts that unequal treatment is a result of a profit-maximizing response by employers to uncertainty about the actual productivity and quality of individual employees. In particular, Blank et al. (2004) analyze that statistical discrimination refers to situations of discrimination on the basis of beliefs that reflect the actual distributions of

\footnotetext{
${ }^{2}$ Psychological research (Herek, 2004) demonstrates the existence of sexual stigma (the shared knowledge of society's negative regard for any behavior, identity, relationship or community that is not heterosexual), heterosexism (the cultural ideology that perpetuates sexual stigma), and sexual prejudice (negative attitudes based on sexual orientation) and the effects that such attitudes have on the everyday experiences of gay male and lesbian people.
} 
characteristics of different groups. In a world of imperfect information, employers face risks regarding employees' profitability, and specific characteristics become inexpensive screening devices (Pager and Karafin, 2009). If employers believe that there is a systematic difference between gay male/lesbian and heterosexual employees in their reliability, aptitude, productivity, work commitment, job stability etc. then differences in employment outcomes may arise (Altonji and Pierret, 2001; Feltovich and Papageorgiou, 2004; Lahey, 2008). Specifically, if employers' uncertainty regarding sexual orientation minorities' productivity, work commitment etc. is strong enough, they will not employ gay male/lesbian people to their works, or they employ them in jobs in which it is easier to monitor their productivity or in jobs for which turnover is not problem. These acts are not based specifically on prejudice or negative affect toward a class of individuals but rather are motivated by practical concerns and negative stereotypes and are grounded in what the decision maker believes to be valid inferences about productivity and risk ${ }^{3}$. Importantly, however, if employer's beliefs are inaccurate or uniformed, it might not be statistical discrimination (Blank et al. 2004).

\footnotetext{
${ }^{3}$ Importantly, although there are evidences that lesbians earn more than heterosexual women in the US (Badgett, 2001; Berg and Lien, 2002; Jepsen, 2007; Daneshvary et al., 2008), in UK (Arabsheibani et al., 2005), and in the Netherlands (Plug and Berkhout, 2004) all correspondence tests suggest that lesbians face statistically significant hiring discrimination in Toronto (Adam, 1981), Austria (Weichselbaumer, 2003), Greece (Drydakis, 2011), and Sweden (Ahmed et al., 2012). Since, discriminatory treatments are assigned we can suggest that statistical discrimination against lesbians might be present at the initial stage of the hiring process. Working in a collaborative spirit, one may suggest that lesbians face entry employment inequalities (driven by taste and/or
} 
Van Hoye and Lievens (2003), as well as, Feltovich and Papageorgiou (2004) evaluate that given limited information, an employer is more likely to resort to negative stereotypes in order to make hiring decisions but the authors highlight the possibility that discrimination is reduced or even eliminated when a decision-maker has enough positive information. The few existing empirical studies provide contradictory outcomes. On the one hand, Kaas and Manger (2011) find that ethnic discrimination in the German labour market is disappeared when favourable information is provided. In the same vein, Lahey (2008) suggest that no evidence is found to support taste-based discrimination as a reason for age discrimination in the US labour market, and some evidence is found to support statistical discrimination. On the other hand, Bosch et al. (2010) show that positive information can not eliminate discriminatory behavior against ethnic minorities in the Spanish housing market. Similarly, in Sweden, Ahmed et al. (2010) estimate that the amount of housing discrimination against ethnic minorities remains unchanged by providing more information about ethnic people. Importantly, however, we should be very careful in the way we interpret these patterns because there are differences depending on how one evaluates the phenomenon under consideration.

statistical motivations) that become wage premiums in the future (Drydakis, 2011). However, this is an open question. As Elmslie and Tebaldi (2007) point out, the level of discriminatory attitudes against lesbians is "indeterminate theoretically". On the one hand, lesbian women could suffer. On the other hand, lesbians may be preferred. 


\section{Design of the experiment}

\section{4.a Methodology and application structure}

This research focuses on the Republic of Cyprus (South Cypriot Cities: Nicosia, Limassol, Larnaca, Paphos) which is administered by Greek Cypriots. The data were gathered between January 2010 and January 2011 as part of the Southern Cypriot Area Study (SCAS) conducted by the Panteion University of Social and Political Sciences. The 2010-2011 SCAS is one component of the multi-city study of the Scientific Center for the Study of Discrimination (SCSD). The current experiment was structured in two stages. In the first stage, we fabricated two imaginary employees equal in human capital. The two applied for the same job by sending application forms using different fax devices (see, Appendix A). We applied to vacancies that demanded eight hours a day and five days a week of either male or female employment. These vacancies were identified through a random sample of advertisements appearing on websites ${ }^{4}$. We concentrated on low-qualified jobs because applicants for such positions are expected to be face greater discrimination risk (Badgett et al. 2007; Eurobarometer, 2007; Drydakis, 2012). Thus, it was our priority to estimate low-qualified people's occupational access, and evaluate then the reasons for such discrimination (Eurobarometer, 2007). We investigated different occupations with vacancies that might demonstrate a variation in discriminatory behavior. The occupations covered a large spectrum of work environments: office jobs, industry jobs, café and restaurant services and shop sales. Other occupations were excluded. For example, many low-qualified job vacancies in

\footnotetext{
${ }^{4}$ In Greek-Cyprus, six internet sites advertise job openings. This is the most expedient way to search for a job. All are also online. We became members of these sites and had a large pool of job openings.
} 
agriculture, construction, cleaning and delivery only had telephone numbers available for contact.

The qualifications and presentation styles of the two fictitious applicants (per sex) were matched as closely as possible. The applicants were identical in all employment-relevant characteristics except sexual orientation. Each of the applicants was given a distinctive first and last Greek Cypriot name, a mobile telephone number, and a postal address. Each of the name combinations alternated between homosexual and heterosexual sexualities. The addresses were chosen in order to indicate the same social class. The applicants were 30 years old, natives and unmarried. Both applicants had finished high school approximately twelve years before, had basic knowledge of English and P/C, and had ten years of work experience in positions similar to the vacant one for which they were applying. Moreover, in order to avoid detection, the candidates' high schools and previous workplaces were located in different areas within each city. Finally, we included items on the resumes to signal that the applicants had similar hobbies (cinema and music).

The application forms were faxed simultaneously and within one day of the advertisement's first appearance. If the firms were interested in any of the applicants, they could be reached either through postal addresses or by telephone. The styles of the cover letters and curriculum vitae were different for each applicant. Pre-tests ensured that neither of the two cover letters and resumes elicited preferences. Nevertheless, the different styles were allocated equally between the heterosexual and gay male/lesbian applicants in order to control for the possibility that the style of a cover letter and curriculum vitae could influence an employer's response. For the same reason, 
applications were sent to each vacancy at different times. In half of the cases, the heterosexual seekers' application was sent first.

In the second stage, whenever employers called to arrange appointments with the applicants, the two applicants asked informal questions regarding monthly wage offers (Drydakis, 2009; 2011). In order to verify that employers were calling, each applicant raised the following questions: "Am I speaking to the employer?" or "Are you the employer?" When we did not have the chance to converse with employers, we did not raise any question regarding monthly wages. This question was reasonable because the status of the vacancies and applicants with low human capital qualifications allowed for straightforward interactions. For low-status vacancies, employers offer fixed wages as robust bargaining tools, and complicated arrangements based on human capital criteria were infrequent (Drydakis, 2009; 2011). In order to verify that the applicants were alike regarding all characteristics, such as articulation, age and manner of speaking, and responses to employers' questions or requests for clarifications, we conducted a pre-test that included a recording of the applicants' rehearsed responses and asked numerous individuals to assess the applicants regarding the relevant issues. The true experiment began after unanimity had been reached. Overall we employed four pairs of applicants (per each sex). However, to control for the effects lacking motivation, we alternated the applicant's role every month. The experiment was designed in order to minimize the inciting of repulsion or endearment by the applicants' words or behavior. Repulsion or endearment may have led to actions having little or nothing to do with wage discrimination. Finally, as in Drydakis $(2009 ; 2011)$, we assumed that the likelihood of employer wage discrimination against gay male/lesbian applicants may vary with characteristics such as the employer's sex. It is of interest to ascertain whether male and 
female employers discriminated against sexual orientation minorities in similar ways. In an attempt to assess the role of these characteristics, the applicants recorded this information when they received callbacks from employers.

\section{4.b Gay male/lesbian labeling}

In this study, as in Adam (1981), Weichselbaumer (2003), Drydakis (2009; 2011), Tilcsik (2011) and Ahmed et al. (2012) the gay male/lesbian applicants' sexual orientations were disclosed by the following line in the personal information part of the resume: "member volunteer in the Cypriot Homosexual Association (from 2005 to 2008)". No explicit information on sexual orientation was given by the heterosexual half of the applicants. The present labeling does suggest that the sexual orientation minority applicant successfully communicates his/her sexual orientation. Herek (1990) explained that homosexuality operates through a dual process of invisibility and attack. It usually remains culturally invisible; when people who engage in homosexual behavior or who are identified as gay male/lesbians become visible, they may become subject to societal attacks. Indeed, Drydakis (2009) discusses that “...after a short period of sending applications, the gay-labeled mobile phone started to receive intimidating calls (from males) regarding sexual orientation, and this lasted up until the end of the experiment...". The potential for discriminatory treatment due to sexual orientation depends on the employers' ability to distinguish gay male/lesbian from heterosexual applicants. Even if employers wish to discriminate against gay male/lesbian employees, there are few ways of judging this aspect of individuals' lives ${ }^{5}$.

\footnotetext{
5 As we mentioned before Southern Cyprus is the most puritanical society in the European Union in terms of general attitudes toward gay male and lesbian people
} 
Researchers acknowledge that a concern with correspondence testing for sexual orientation is that the interaction of volunteerism/activism and sexual orientation may be important (Drydakis, 2011; Tilcsik, 2011). Generally talking, activists in any field could be also subjected to discrimination on the basis of political opinions and beliefs. It may also be possible that they receive preferential treatment. The two scenarios described remain controversial given the absence of empirical evaluation. In this study, the heterosexual applicants' curriculum vitae also mentioned past volunteerism in an environmental association; "Volunteer in the Nature: Environmental Union from 20052008”. Similarly, being a member of this association may, positive or negative, affect employment possibilities and wages. Crucially, however, both documents indicated that those activities had ended in order to minimize the volunteerism/activism impact. In doing so, we control also, for the chance that volunteerism/activism may have created a conflict in the applicants' present duties (see also Weichselbaumer, 2003; Drydakis, 2009; 2011; Tilcsik 2011).

\section{4.c Enhance applications' information}

As previously discussed there is a consensus among economists that discrimination may be caused by preferences for and against members of certain groups

(Eurobarometer, 2006; 2007). We suggest that it would not have been rational for Cypriot heterosexuals to highlight in their CVs gay male and lesbian activism. However, in those countries where people are tolerant regarding gay male and lesbian rights, and heterosexual people support gay male and lesbian movements, correspondent test results should be interpreted as discrimination against "potentially" gay males and lesbians. 
and/or the lack of correct information about their skills, reliability and work commitment (Feltovich and Papageorgiou, 2004; Charles and Guryan, 2008; Pager and Karafin, 2009). Since taste and statistical discrimination can most likely coexist, we can only rule out the preference-based explanation if discrimination is eliminated after adding positive information about applicants (Feltovich and Papageorgiou, 2004; Van Hoye and Lievens, 2003). In the current study, we hypothesize that adding information to the application should not reduce the gap between sexual orientation minority applicants in the number of response and wage offers if discrimination is a result of firms' preferences for heterosexual applicants. However, it should decrease the gaps in the number of responses, as well as in wages offers received from firms between gay male/lesbian and heterosexual applicants if discrimination is caused by uncertainty (see also, Lahey, 2008; Ahmed et al. 2010; Bosch et al. 2010).

Methodologically, we created two additional applicants, one gay male/lesbian labeled and one heterosexual (for each sex) who gave favorable information about themselves; the so-called 'more-informative applicants' (see, Appendix B), and we experimented with two information sets the 'sexual orientation' and 'information' of the potential applicants. Thus, we had four different types of matched pairs and we randomized the particular application information (see, Appendix C). Firstly, we studied the extent to which the applicants received callbacks from firms, and initial wage offers. Secondly, we examined the difference between the applicants who had provided low information about themselves, and applicants who had provided favorable information about themselves. For obvious reasons, we sent a pair of applications for each job opening. The experiment would have been revealed if we had sent a more-informative 
gay male/lesbian and less-informative gay male/lesbian application to the same job opening.

In this study, we added positive information on factors where gay male/lesbian employees may potentially suffer from prejudice; that is work commitment. Typically, statistical discrimination is discussed with respect to discrimination against women and ethnic minorities. In these cases gender roles and cultural norms may lead to differences in average education and productivity leaving the minority group at a disadvantage. This is not the case for gay males and lesbians who are usually well educated (Badgett et al., 2007). However, since sexual orientation minorities enjoy lower societal approval than heterosexuals (Eurobarometer, 2006; 2007, Badgett et al., 2007) potential biases could predict differences for the labour market commitment and labour behavior between heterosexual and gay males/lesbians, which fit in standard models of statistical discrimination such as Phelps (1972). Methodologically, we screened the resumes with human resource officials in public and private employment settings in order to assure that applicants' labour market commitment is signaled.

Employers often believe grading scales are useful predictors of cognitive ability that affects effectiveness and responsibility and they make hiring decisions that are based on them (Roth et al., 1996; Miller, 1998; Turban and Cable, 2003; Kaas and Manger, 2011). The more-informative applicants mentioned their high school diplomas grading scale (very good); their first degrees in English grade (A); and their certificates of $\mathrm{P} / \mathrm{C}$ knowledge grade (A). Moreover, the CVs were more informative regarding applicants' previous responsibilities and job tasks. Furthermore, they mentioned some personal characteristics to emphasize their extroversion (sociable, amiable, energetic, enthusiastic) and conscientiousness (efficient, organized, productive). In actuality, 
informative applications regarding previous job responsibilities, as well as, the mentioned personality traits (non-cognitive traits) are key elements which affect market behavior (Boudreau et al., 2001; Turban and Cable, 2003; Muller and Plug, 2006; Hallinger and Bridges, 2007; Kaas and Manger, 2011). Finally, to enhance applicants' reliability, and work commitment the more-informative applicants attached letters of reference from previous employers ${ }^{6}$ stating positive information about the applicants' traits such as affability, capacity for teamwork, efficiency, conscientiousness, responsibility, loyalty to the firm, willingness to exert effort on behalf of the firm, no absenteeism from work, and agreeableness. Studies do confirm the validity of recommendations to signal reliability and work stability in the screening process (Hallinger and Bridges, 2007; Kaas and Manger, 2011). On average, the mentioned studies suggest that applicants' work behavior can be signaled by grading scales, personal characteristics, previous job tasks, and letters of reference. If employers can accurately estimate differences in the quality or disposition of minorities and majorities on average, this information can be helpful in guiding decisions about individual minority and majority candidates for whom these characteristics are more difficult to observe directly. Thus, comparing the response rate across 'sexual orientation' and 'information' could allow us to study taste-based and statistical discrimination in the labour market.

\footnotetext{
${ }^{6}$ The letters of reference were different for each applicant. These were allocated equally between the sexual orientations in order to control for the possibility that one could influence an employer's response. Pre-tests ensured that neither of the two letters gained preferences.
} 


\section{Descriptive statistics}

\section{5.a Less-informative applicants}

The occupational access outcomes are displayed in Tables 1 and 2 for those applicants who have provided limited information. As it can be seen in the last two columns in Table 1, the net discrimination against the gay males occurred in 469 cases, or $71.9 \%$. In Table 2, we see that the net discrimination against lesbians is $76.7 \%$. The findings revealed significant occupational access differences for the two pairs across all sectors, suggesting that bias against gay males and lesbians is widespread. Importantly, in all cases, lesbians face higher net discrimination than gay males. This outcome might highlight sexual orientation minority women's status in the labour market (Drydakis, 2011). Moreover, the measurements show that in more prestigious jobs (office jobs), gay males and lesbians face higher occupational access constraints than in less prestigious jobs (industry, restaurant and café services, and shop sales). Discrimination against sexual orientation minorities might be assumed to be higher in jobs with higher status; thus, occupational segregation is expected to be more prevalent in white-collar than in blue-collar jobs (Drydakis, 2011).

[Table 1]-[Table 2]

Table 3, presents the entry wage offers to heterosexual and gay males/lesbians. The samples used in this study consist of 397 observations for heterosexual males and 103 observations for gay males. While the gay males were similar to their heterosexual counterparts in age, education level, and work experience, the data suggest that male heterosexual applicants were offered monthly wages, on average, higher than the gay 
males: $€ 1141.6$ versus $€ 1034.2^{7}$. On this basis, it seems that sexual orientation does have an effect on observable outcomes. In addition, for female heterosexual and lesbian applicants the wage offers are $€ 1082.6$ and $€ 1016.0$. In all cases, females are found to face lower monthly wages than males, regardless of their sexual orientations. In other words, an entry-based sex wage gap exists. Notice also that, for both majority and minority applicants, the blue-collar jobs (industries) constitute the least well-paid occupation in the current sample. Those applicants in white-collar occupations (office jobs) were offered the highest wages in this sample.

[Table 3]

\section{5.b More-informative applicants}

Would more information about a particular applicant reduce the occurrence of discrimination or are members of minority groups stigmatized by their sexual orientation? Comparisons of the applicant's sexual orientation and the amount of information revealed could allow us to measure the degree of discrimination and learn about its sources. Table 4 shows the occupational access results for more-informative male applicants. As it is observed, the net discrimination against gay males is $72.1 \%$. This finding suggests that adding information in the application increases the gay males' occupational access constrains by $0.2 \%$. Importantly, note that, adding information in the application increases the probability of receiving a callback for both heterosexuals and gay males. However, for gay males the rate of increase is lower. To be precise, adding job-related information in the heterosexual males' application

\footnotetext{
${ }^{7}$ In Cyprus, for the period 2010-11, the minimum legal monthly wage for unmarried workers without experience (approximately) was $€ 830$.
} 
increases their occupational access by $11.3 \%$. On the other hand, adding job-related information in the gay males' application increases their occupational access by $9.5 \%$. Comparable patterns hold for heterosexual and lesbian women (see, Table 5). From the descriptive statistics we can infer that gay males and lesbians did not gain as much as the heterosexual applicants by providing positive information. More importantly, the occupational access gap between sexual orientation minority and heterosexual applicants did not decrease from when they provided less information to when they provided further information about themselves. The informational premium for sexual orientation minority applicants cannot reduce the discriminatory patterns. It is indicated that labour market discrimination against gay male and lesbian applicants is probably a matter of preference, not the result of a lack of information and uncertainty about applicants' work behavior.

\section{[Table 4] - [Table 5]}

Similarly, in Table 6 we observe that the wage gap between more-informative heterosexual and gay male/lesbian applicants is higher than the wage gap between lessinformative heterosexual and gay male/lesbian applicants. Actually, the provision of information raises heterosexual male applicants' monthly wages by $2.3 \%$ (for female heterosexuals the change is on the order of $4.6 \%$ ), while for gay males the wage offers are raised by $1.9 \%$ (for lesbians the wage offers are raised by $2.2 \%$ ). Both heterosexual and gay males/lesbians gain by providing more information. However, adding information to the application does not reduce the discriminatory gap between gay male/lesbian applicants in the entry wage offers.

[Table 6] 


\section{Estimations}

Table 7 presents the occupational access regression results for men and women (Bertrand and Mullainathan, 2004; Drydakis, 2009; Ahmed et al., 2010; Bosch et al., 2010). For convenience, Appendix D summarizes the variable definitions. Panel I shows that the estimated probability (marginal effects) of less-informative gay male applicants receiving an invitation for an interview is 38.9 percentage points lower than that for less-informative heterosexual male applicants, where the result is statistically significant at the 1 percent level. The estimations provide evidence that the sexual orientation minority applicant would receive fewer interview callbacks when two identical applicants engaged in an identical job search. Because of the limited number of positions available, these differences in offers rates imply welfare losses for sexual orientation minorities. One question, then remains to be examined; does the magnitude of discrimination against gay males change when the applicants provide more information about themselves? Panel II presents that the probability of moreinformative gay males receiving an invitation for an interview is 39.2 percentage points lower than that for more-informative heterosexual males. The estimation is statistically significant at the 1 percent level. Consequently, increasing the amount of information in the applications will not reduce occupational access discrimination in the labour market.

Panel III presents regression results for the total sample; less- and moreinformative applicants. The probability of gay males receiving an invitation for an interview is 39.0 percentage points lower than that for heterosexual males. On the one hand, the estimations indicate that, applicants who provide more information have a higher probability of receiving callbacks, where the result is statistically significant at the 1 percent level. On the other hand, however, the interaction effect; "sexual 
orientation $x$ more-informative applications" indicates that discrimination against gay males does not change when gay males provide further information. In other words, the difference in occupational access rates between less-informative heterosexual male and gay males is not statistically significant different from the difference in occupational access rates between more-informative heterosexual males and gay males.

For women, the estimations are 42.4 percentage points lower for lessinformative lesbian applicants, and 43.4 percentage points lower for more-informative lesbian applicants (Panels IV and V). In all cases, the results are statistically significant at the 1 percent level. As it is observed, the interaction effect is again statistically insignificant (Panel VI). Importantly, it is estimated that lesbians face higher occupational barriers to new vacancies than gay males. This pattern is compatible with some European studies reviewed in this study (Drydakis 2009; 2011). The additional effect that having a lesbian background has on females' lives is of great concern and needs further evaluating. Social scientists should place an emphasis on the complex relationship between different types of inequalities, as they are concerned with not only gender relations but also the role of other types of social relations in the determination of occupational access outcomes.

As far as it concerns the other control variables, neither the cover letter's type nor the CV's type has a statistically significant effect. Similarly, the order in which the applications were sent, as well as, letters of reference's type had no significant effect. Note also that, the interaction terms between the sexual orientation dummy and occupation dummies are negative and statistically significant at the 1 percent level. In each occupation, gay males and lesbians faced significantly lower chances of being invited for an interview. As Drydakis (2009) claims, gay people are more likely to be 
unemployed than heterosexuals, assuming that an applicant receives an interview only if he/she has a substantial chance of getting the job.

The current estimations agree with Adam's (1981), Weichselbaumer's (2003), Drydakis's (2009, 2011), Tilcsik's (2011) and Ahmed's et al. (2012) Correspondence Testing results. They find a statistically significant reduction in the invitation rates for applicants labeled as gay male/lesbian applicants. Apparently, the estimates in this study are higher than those in the studies cited. This pattern has two explanations. In the current experiment, the investigation focused on low qualified gay male/lesbian applicants. Adam (1981), Weichselbaumer (2003) and Tilcsik (2011) structured experiments to test the performance of qualified men and women, such as lawyers, managers, business and financial analysts, accountants, and administrative assistants. The issue of sexual orientation might be complicated by the wide variety of firmspecific labour market forms, the strong influence of occupational factors in determining employment practices, and their impact on gay males' and lesbian's employment positions and prospects, as well as the problems associated with making comparisons at the sectoral level across different markets. On the other hand, the Eurobarometer (2007) measures Cyprus as the most puritanical society in Europe when it comes to general attitudes toward homosexuality. Cyprus is perceived to be strongly reluctant to deal with issues such as sexual orientation in the labour market compared to Sweden, Austria and Greece (Eurobarometer, 2006; 2007).

To continue with, Table 8 presents the wage coefficients (OLS). The negative effect of minority sexual orientation is significant in all panels at the 1 percent level. For less-informative gay males the estimated wage bias is 9.0 percent lower (Panel I), for more-informative gay males it is 9.5 percent lower (Panel II), and for both less- and 
more-informative gay males it is 9.2 percent lower (Panel III) ${ }^{8}$. Moreover, for lessinformative lesbians the estimated wage bias is 5.6 percent lower (Panel IV), for moreinformative lesbians it is 5.9 percent lower (Panel V), and for both less- and moreinformative lesbians it is 5.8 percent lower (Panel VI). In all cases, applicants who provide more information were offered higher wages, where the results are statistically significant. However, the interaction effect estimator is statistically insignificant. The wage estimations indicate that gay male and lesbian applicants are at disadvantage in the labour market and that this discrimination persists even when applicants provide detailed information about themselves. Note also that lesbians face lower wage bias than gay males ${ }^{9}$.

${ }^{8}$ Indeed, in the literature, there is strong evidence of wage discrimination against gay males. In UK, Arabsheibani et al. (2005) find that gay males earn less than heterosexual males. In Sweden, Ahmed and Hammarstedt (2010) estimate that gay males earn less than heterosexual males. In Greece, Drydakis (2012) finds that gay males earn less than heterosexual males. In the US, Black et al. (2003) estimate comparable patterns.

${ }^{9}$ The general trend in the literature suggests that lesbian employees may earn more than (or the same as) heterosexual women (Arabsheibani et al. 2005; Jepsen, 2007; Ahmed and Hammarstedt, 2010). These patterns can be evaluated through human capital accumulation and specialization choices, household formation, work effort, location, spending, and personality characteristics (Drydakis, 2011; 2012). In the current study, however, lesbians face significant entry wage bias than heterosexual women. As previously discussed, Cyprus is perceived to be strongly reluctant to deal with issues such as sexual orientation in the labour market, and also it is ranked as the most puritanical society in Europe when it comes to general attitudes toward homosexuality 
In the wage regressions, the order in which the application was sent, the cover letter, CV and letters of reference type, the employers' callback order, the interaction effect between the sexual orientation dummy and employers' callback order, the applicant's impact ${ }^{10}$, and the interaction between the sexual orientation dummy and applicant's impact were found to have insignificant effects on wage offers. However, the interactions between the sexual orientation dummy and occupation dummies are significant. As the descriptive statistics suggested, wage offers are statistically significantly different for gay males/lesbians and heterosexuals. Furthermore, employers' gender had insignificant effect on wage offers. Similarly, the interaction effect between the sexual orientation dummy and employers' gender is statistically insignificant.

\section{Discussion}

This study attempted to evaluate the role of preference-based and statistical discrimination in the Cypriot labour market by directly observing the change in the behavior of the firms by manipulating the information provided in applicants' resumes.

(Eurobarometer, 2006; 2007). These attitudes may affect lesbians' entry wages offers (see, also Drydakis, 2011).

${ }^{10}$ Since four pairs of applicants (for each gender) were used in this study, a test of homogeneity across pairs was undertaken to check whether or not one or more pairs of applicants were driving the results. Eventually, we accept the null hypothesis of homogeneity at the $1 \%$ level. This implies the success of efforts to control for participants' effects that might have biased the occupational access and entry wage outcomes. 
We hypothesized that increasing information about the applicants should not affect the amount of discrimination against sexual orientation minorities if discrimination was preference based, but it should decrease the discrimination against minorities if part of the discrimination was statistical. The results showed that the extent of discrimination against gay male/lesbian applicants after adding information remains unchanged.

Neumark (1999) suggests that from a policy perspective, whether taste discrimination or statistical discrimination plays a major role in differences in labour market outcomes between majorities and minorities is significant. If taste discrimination accounts for the lower occupational access and entry wages of gay male/lesbian applicants, then antidiscrimination legislation may be the only appropriate response. However, if statistical discrimination is important, then a better means of assessing employees' productivity, skill and ability may contribute to the reduction of discrimination at the individual or group level (Altonji, and Pierret, 2001). As employees accumulate experience on the job, employers may acquire new information about performance/abilities and re-evaluate hiring standards, wage contracts and promotion decisions. In the current study, since, negative attitudes against gay male/lesbian people is the source of discrimination, one strategy the Cypriot government may employ is to try to affect public opinion and people's attitudes towards gay males and lesbians. Depriving people of an equal opportunity to a job that maximizes their human potential based on sexual orientation or any other attribute is a serious threat not only to a person's economic welfare but also to their sense of citizenship (Kalleberg, 2009). The current findings are especially striking when considered in the context of legislation aimed at securing improvements in the labour market position of minorities in Cyprus. To date, Cyprus has not had the opportunity to 
devote substantial resources to public education in the area of employment, which is apparent in the public's general lack of awareness regarding the legal protection against unequal treatment. The lack of a controlled, public, educational, and informational instrument is a decisive factor preventing achievement of labour equality. The objective of eliminating this type of discrimination requires the mitigation of sexual prejudice and negative stereotypes and norms on the part of firms. That means information and affirmative action are required in order to regulate sexual-orientation minorities' access to and terms of employment.

Importantly, note that without further research, we cannot generalize the results of this study to other kinds of applicants, vacancies, employers, and cultures. Thus, many questions are left unanswered. This study focuses on the hiring stage and ignores potential discrimination that could arise later. In addition, the present estimates hold for low-wage, low-qualified people only. Labour market outcomes may be different for highly qualified people applying for more sophisticated vacancies. Moreover, if gay male and lesbian employees experience losses in earnings because they more frequently end up in dead-end jobs or face glass ceilings, estimates based on starting positions would not pick up these effects. Furthermore, in reality, job offers are also obtained via informal searches and networks. Moreover, given the low level of factual knowledge on characteristics that are valued by employers and how personal attributes traded off against profitability content, and the heterogeneity among employers in making these assessments, it was not obvious that we possessed the relevant information required to make perfect matches. There may be other relevant variables for the hiring decision that may differ across sexual groups and are missing in the resumes sent. Thus, the results of 
this study are simply an indication of the relationship between sexual orientation and employment outcomes but are by no means the final word. 


\section{References}

Adam, B. D. (1981). Stigma and Employability: Discrimination by Sex and Sexual Orientation in the Ontario Legal Profession. Canadian Review of Sociology and Anthropology, 18: 216-221.

Ahmed, A. M. Andersson, L. and Hammarstedt, M. (2008). Are Lesbians Discriminated Against in the Rental Housing Market: A Correspondence Testing Experiment. Journal of Housing Economics, 17: 234-238.

Ahmed, A. and Hammarstedt, M. (2009). Detecting Discrimination Against Homosexuals: Evidence from a Field Experiment on the Internet. Economica, 76:588-597.

Ahmed, A. M. Andersson, L. and Hammarstedt, M. (2010). Can Discrimination in the Housing Market Be Reduced by Increasing the Information about the Applicants? Land Economics, 86: 79-90.

Ahmed, A. M. and Hammarstedt, M. (2010). Sexual Orientation and Earnings: A Register Data-Based Approach to Identify Homosexuals. Journal of Population Economics, 23: 835-849.

Ahmed, A. M. Andersson, L. and Hammarstedt, M. (2012). Are Gay Men and Lesbians Discriminated Against in the Hiring Process? Southern Economic Journal, forthcoming. 
Altonji, J. G. and Pierret C. R. (2001). Employer Learning and Statistical Discrimination. Quarterly Journal of Economics, 116:313-350.

Arabsheibani, G. R. Marin, A. and Wadsworth, J. (2005). Gay Pay in the UK, Economica, 72:333-347.

Arrow, K. J. (1973). The Theory of Discrimination, in Discrimination in Labor Markets, Ashenfelter O. and Rees A. (eds). New Jersey: Princeton University Press.

Arrow, K. J. (1998). What Has Economics to Say about Racial Discrimination? Journal of Economic Perspectives, 12:91-100.

Badgett, M. V. L. (2001). Money, Myths, and Change: The Economic Lives of Lesbians and Gay Men. Chicago: University of Chicago Press.

Badgett, M. V. L. Lau, H. Sears, B and Ho, D. (2007). Bias in the Workplace: Consistent Evidence of Sexual Orientation and Gender Identity Discrimination. The Williams Institute, UCLA School of Law.

Baumle, K. A. and Fossett, M. (2005). Statistical Discrimination in Employment. Its Practice, Conceptualization, and Implications for Public Policy. American Behavioral Scientists, 48: 1250-1274. 
Becker, G. S. (1957). The Economics of Discrimination. Chicago: University of Chicago Press.

Becker, G. S. (1993). Nobel Lecture: The Economic Way of Looking at Behavior. Journal of Political Economy: 101: 385-409.

Berg, N. and Lien. D. (2002). Measuring the Effect of Sexual Orientation on Income: Evidence of Discrimination? Contemporary Economic Policy, 20: 394-414.

Bertrand, M. and Mullainathan, S. (2004). Are Emily and Greg More Employable Than Lakisha and Jamal? A Field Experiment on Labor Market Discrimination. American Economic Review, 94: 991-1013.

Black, D. A., Hoda, R. M., Seth, S. and Lower, T. (2003). The Earnings Effects of Sexual Orientation. Industrial and Labour Relations Review, 56: 449-469.

Blank, R. M. Dabady, M. and Citro, C. F. (2004). Measuring Racial Discrimination. Washington, D. C.: National Academy Press.

Bosch, M. Carnero, A. and Farre, L. (2010). Information and Discrimination in the Rental Housing Market: Evidence from a Field Experiment. Regional Science and Urban Economics, 40: 11-19. 
Boudreau, J. W. Boswell, W. R. Judge, T. A. (2001). Effects of Personality on Executive Career Success in the United States and Europe. Journal of Vocational Behavior, 58:53-81.

Brue, S. L. Macpherson, D. A. and McConnell, C. R. (2006). Contemporary Labor Economics. NewYork: McGraw-Hill/Irwin.

Charles, K. K. and Guryan, J. (2008). Prejudice and Wages: An Empirical Assessment of Becker's The Economics of Discrimination. Journal of Political Economy, 116:773-809.

Council Directive 2000/78/EC of 27 November 2000. Establishing a General Framework for Treatment in Employment and Occupation. Official Journal of the European Communities, 303: 0016-0022.

Daneshvary, N. C. Waddoups, J. and Wimmer, B. S. (2008). Educational Attainment and the Lesbian Wage Premium. Journal of Labor Research, 29: 365-379.

Drydakis, N. (2009). Sexual Orientation Discrimination in the Labor Market. Labour Economics, 16: 364-372.

Drydakis, N. (2011). Women's Sexual Orientation and Labor Market Outcomes in Greece. Feminist Economics, 11:89-117. 
Drydakis, N. (2012). Sexual Orientation and Labor Relations: New Evidence from Athens Greece. Applied Economics, 44: 2653-2665.

England, P. (1994). Neoclassical Economists' Theories of Discrimination, in Burstein, P., (ed.), Equal Employment Opportunity: Labor Market Discrimination and Public Policy. NewYork: Walter de Gruyter.

Elmslie, B. and Tebaldi, E. (2007). Sexual Orientation and Labor Market Discrimination. Journal of Labor Research, 28: 436-453.

Eurobarometer. (2006). Public Opinion in the European Union. Standard Eurobaromete, Wave 66. Brussels: European Commission.

Eurobarometer. (2007). Discrimination in the European Union, Wave 65.4. Brussels: European Commission.

European Union Agency for Fundamental Rights. (2008). Legal Study on Homophobia and Discrimination on Grounds of Sexual Orientation - Cyprus. Vienna.

European Union Agency for Fundamental Rights. (2009). Homophobia and Discrimination on Grounds of Sexual Orientation and Gender Identity in the European Union Member States, Part II-The Social Situation. Vienna. 
Feltovich, N. and Papageorgiou, C. (2004). An Experimental Study of Statistical Discrimination by Employers. Southern Economic Journal, 70: 837-849.

Hebl, M. R. Foster, B. J. Mannix, L. M. and Dovidio, J. F. (2002). Formal and Interpersonal Discrimination: A Field Study of Bias Toward Homosexual Applicants. Personality and Social Psychology Bulletin, 28: 815-825.

Herek, G. M. (1990). The Context of Anti-Gay Violence: Notes on Cultural and Psychological Heterosexism. Journal of Interpersonal Violence, 5: 316-333.

Herek, G. (2004). Beyond Homophobia: Thinking About Sexual Prejudice and Stigma in the Twenty-First Century. Sexuality Research and Social Policy 1: 6-24.

Hallinger, P. and Bridges, E. M. (2007). Employee Selection, In, A Problem Based Approach for Management Education, Hallinger, P. and Bridges, E. M. (Eds). Springer, Netherlands.

Jaret, C. (1995). Contemporary Racial and Ethnic Relations. New York: Harper Collins.

Jepsen, L. K. (2007). Comparing the Earnings of Cohabiting Lesbians, Cohabiting Heterosexual Women, and Married Women: Evidence from the 2000 Census. Industrial Relations, 46: 699-727. 
Jowell, R. and Prescott-Clarke, P. (1970). Racial Discrimination and White-Collar Workers in Britain. Race, 11:397-417.

Kalleberg, A. L. (2009). Precarious Work, Insecure Workers: Employment Relations in Transition. American Sociological Review, 74:1-22.

Kaas, L. and Manger, C. (2011). Ethnic Discrimination in Germany’s Labour Market: A Field Experiment. German Economic Review, 13: 1-20.

Lahey, J. (2008). Age, Women, and Hiring. An Experimental Study. Journal of Human Resources, 43: 30-56.

Lauster, N. and Easterbrook, A. (2011). No Room for New Families? A Field Experiment Measuring Rental Discrimination Against Same-Sex Couples and Single Parents. Social Problems, 58: 389-409.

Makkonen, T. (2007). European Handbook on Equality Data, carried out for the Finnish Ministry of Labour, European Commission, Directorate-General for Employment, Social Affairs and Equal Opportunities, Luxembourg.

Miller, S. R. (1998). Shortcut: High School Grades as a Signal of Human Capital. Educational Evaluation and Policy Analysis, 20:299-311. 
Neumark, D. Bank, R. J. and Van Nort, K. D. (1996). Sex Discrimination in Restaurant Hiring: An Audit Study. Quarterly Journal of Economics, 111:915-941.

Neumark, D. (1999). Wage Differentials by Race and Sex: The Roles of Taste Discrimination and Labor Market Information. Industrial Relations, 38: 414-445.

Onoufriou, A. (2009). 'Falling in Love With Someone From Your Own Sex Is Like Going Against Cyprus Itself ...' - Discourses Towards Heterosexual and Femaleto-Female Subjectivities at the University of Cyprus. Journal of Gender Studies, $18: 13-23$.

Pager, D. D. and Karafin, D. (2009). Bayesian Bigot? Statistical Discrimination, Stereotypes, and Employer Decision Making. ANNALS of the American Academy of Political and Social Science, 621: 70-93.

Phelps, E. S. (1972). The Statistical Theory of Racism and Sexism. American Economic Review, 62: 659-661.

Plug, E. and Berkhout, P. (2004). 'Effects of Sexual Preferences on Earnings in the Netherlands. Journal of Population Economics, 17: 117-31.

Reiss, B. F. Safer, J. and Yotive, W. (1976). Psychological Test Data on Female Homosexuality: A Review of the Literature. Journal of Homosexuality 1: 71-86. 
Riach, P. A. and Rich, J. (2002). Field Experiments of Discrimination in the Market Place. The Economic Journal, 112: 480-518.

Roth, P. L. BeVier, C. A. Switzer, F. S. Schippmann, J. S. (1996). Meta-Analyzing the Relationship Between Grades and Job Performance. Journal of Applied Psychology, 81:548-556.

Tilcsik, A. (2011). Pride and Prejudice. Employment Discrimination Against Openly Gay Men in the United States. American Journal of Sociology, 117: 586-626.

Turban, D. B. and Cable, D. M. (2003). Firm Reputation and Applicant Pool Characteristics. Journal of Organizational Behavior, 24: 733-751.

Van Hoye, G. and Lievens, F. (2003). The Effects of Sexual Orientation on Hirability Ratings: An Experimental Study. Journal of Business and Psychology, 18:15-30.

Weichselbaumer, D. (2003). Sexual Orientation Discrimination in Hiring. Labour Economics 10: 629-642.

Weichselbaumer, D. (2004). Is it Sex or Personality? The Impact of Sex Stereotypes on Discrimination in Applicant Selection. Eastern Economic Journal, 30: 159-186. 
Table 1. Aggregate correspondence test results for less-informative applicants: Heterosexual males vs. gay males

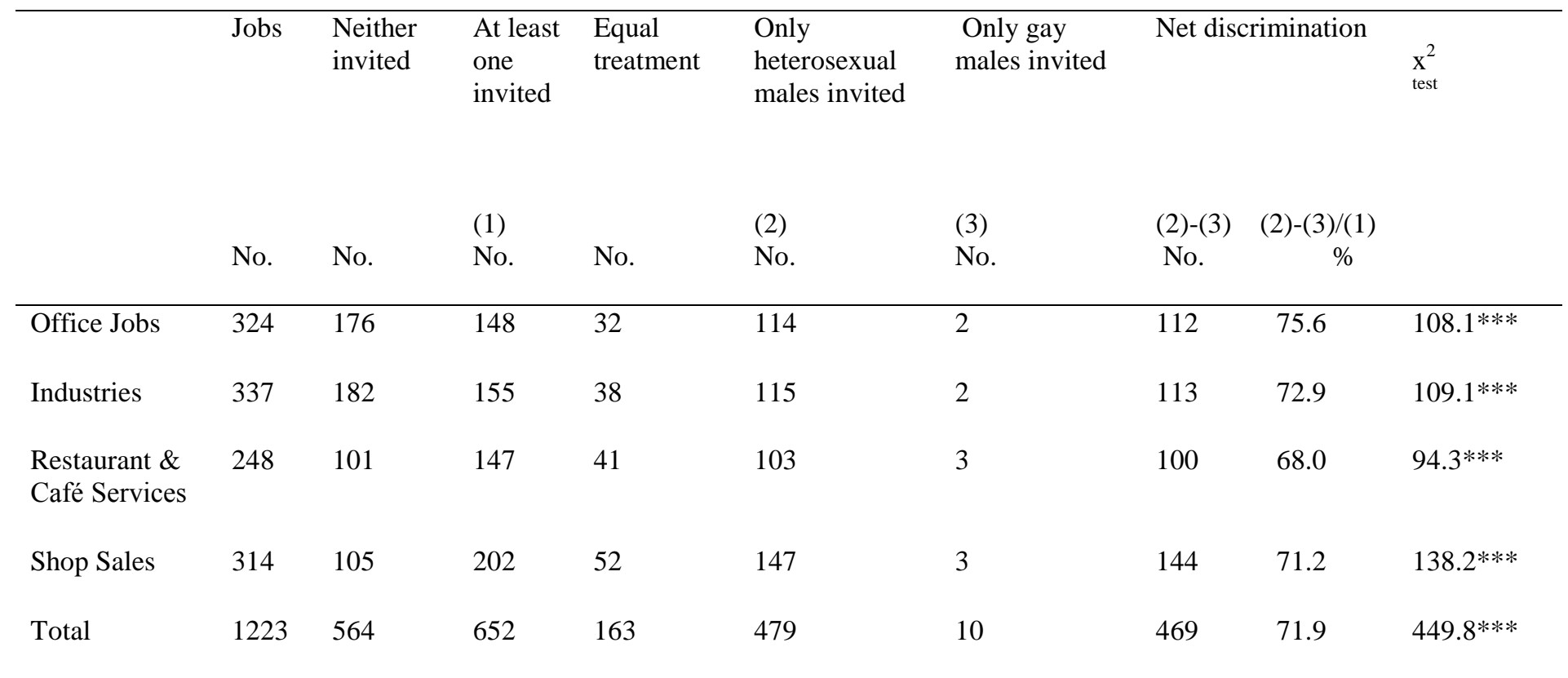

Note: The null hypothesis is that "Both individuals are treated unfavorably equally often", that is, (2)=(3). (***) Statistically significant at the $1 \%$ level. 
Table 2. Aggregate correspondence test results for less-informative applicants:

Heterosexual females vs. lesbians

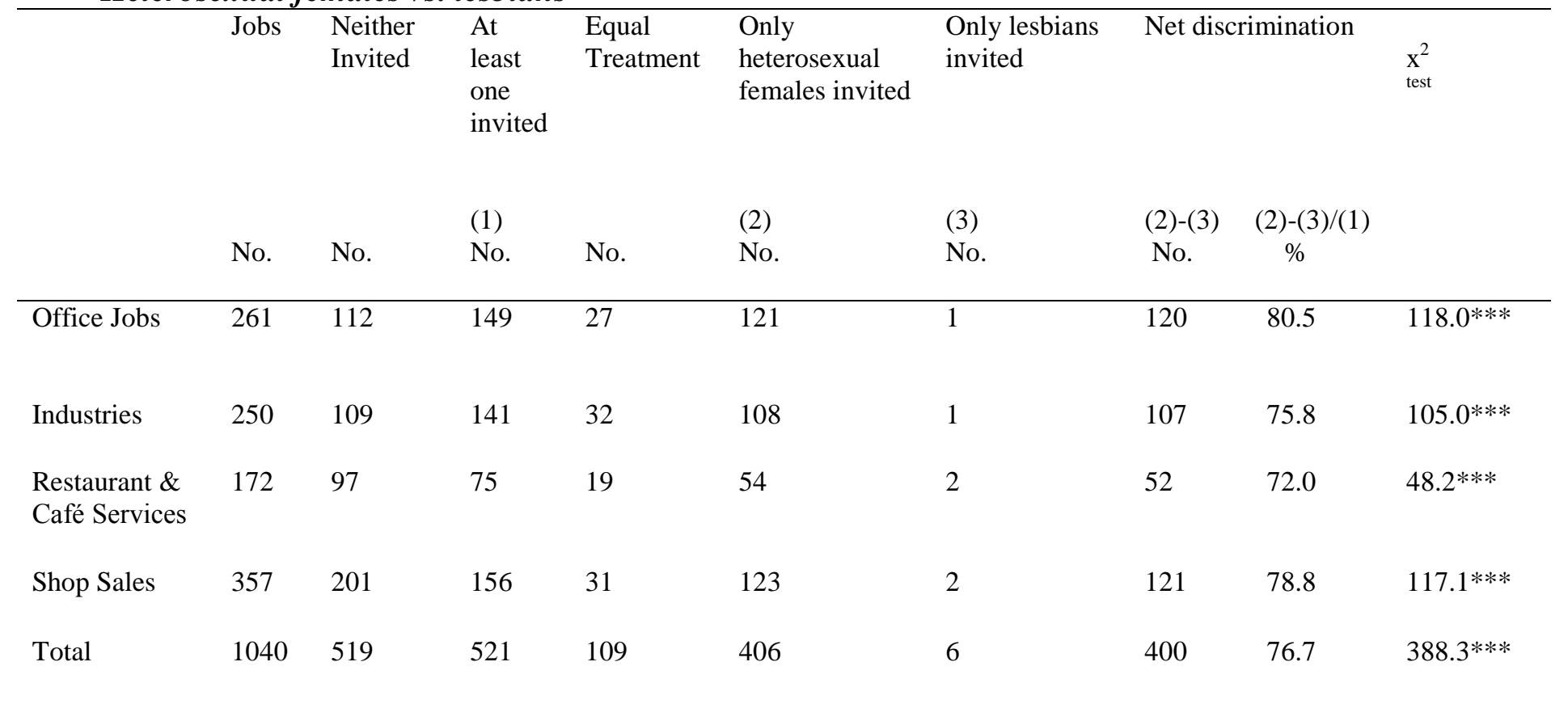

Note: The null hypothesis is that "Both individuals are treated unfavorably equally often", that is, (2)=(3). (***) Statistically significant at the $1 \%$ level. 
Table 3. Mean monthly wage offers ( $€$ ) for less-informative applicants:

Heterosexual males (females) vs. gay males (lesbians)

\begin{tabular}{|c|c|c|c|c|c|c|c|c|}
\hline & $\begin{array}{l}\text { Heterosexual } \\
\text { males }\end{array}$ & $\begin{array}{l}\text { Gay } \\
\text { males }\end{array}$ & $\begin{array}{l}\text { Raw } \\
\text { difference }\end{array}$ & $\begin{array}{l}\text { Difference } \\
\text { test } \\
\text { (t-test) }\end{array}$ & $\begin{array}{l}\text { Heterosexual } \\
\text { females }\end{array}$ & Lesbians & $\begin{array}{l}\text { Raw } \\
\text { difference }\end{array}$ & $\begin{array}{l}\text { Difference } \\
\text { test } \\
\text { (t-test) }\end{array}$ \\
\hline Office Jobs & $1308.5(88)$ & $1186.6(21)$ & 121.9 & $3.1 * * *$ & $1119.4(108)$ & $1064.5(10)$ & 54.9 & $2.5 * * *$ \\
\hline Industries & $1131.7(82)$ & $1016.4(17)$ & 115.3 & $3.2 * * *$ & $1080.8(78)$ & 1010.5 (19) & 70.3 & $2.8 * * *$ \\
\hline $\begin{array}{l}\text { Restaurant } \\
\text { \& Café } \\
\text { Services }\end{array}$ & $1117.8(84)$ & $1035.8(29)$ & 82.0 & $2.6 * * *$ & $1042.0(43)$ & $1011.1(9)$ & 30.9 & $2.5 * * *$ \\
\hline Shop Sales & $1100.9(143)$ & $1042.1(36)$ & 58.8 & $3.0 * * *$ & $1060.1(81)$ & $1023.5(20)$ & 36.6 & $2.2 * * *$ \\
\hline Total & $1141.6(397)$ & $1034.2(103)$ & 107.4 & $3.9 * * *$ & $1082.6(310)$ & $1016.0(58)$ & 66.6 & $2.9 * * *$ \\
\hline
\end{tabular}

Note: (***) Statistically significant at the 1\% level. The number of observations is in parentheses. 
Table 4. Aggregate correspondence test results for more-informative applicants:

Heterosexual males vs. gay males

\begin{tabular}{|c|c|c|c|c|c|c|c|c|c|}
\hline & Jobs & $\begin{array}{l}\text { Neither } \\
\text { invited }\end{array}$ & $\begin{array}{l}\text { At least } \\
\text { one } \\
\text { invited }\end{array}$ & $\begin{array}{l}\text { Equal } \\
\text { treatment }\end{array}$ & $\begin{array}{l}\text { Only } \\
\text { heterosexual } \\
\text { males invited }\end{array}$ & $\begin{array}{l}\text { Only gay } \\
\text { males invited }\end{array}$ & Net dis & rimination & $\begin{array}{l}\mathrm{x}^{2} \\
\text { test }\end{array}$ \\
\hline & No. & No. & $\begin{array}{l}(1) \\
\text { No. }\end{array}$ & No. & $\begin{array}{l}(2) \\
\text { No. }\end{array}$ & $\begin{array}{l}(3) \\
\text { No. }\end{array}$ & $\begin{array}{l}(2)-(3) \\
\text { No. }\end{array}$ & $\begin{array}{c}(2)-(3) /(1) \\
\%\end{array}$ & \\
\hline Office Jobs & 305 & 154 & 151 & 26 & 123 & 2 & 121 & 80.1 & $117.1 * * *$ \\
\hline Industries & 341 & 162 & 179 & 56 & 122 & 1 & 121 & 67.5 & $119.0 * * *$ \\
\hline $\begin{array}{l}\text { Restaurant \& } \\
\text { Café Services }\end{array}$ & 259 & 93 & 166 & 50 & 114 & 2 & 112 & 67.4 & $108.1 * * *$ \\
\hline Shop Sales & 295 & 90 & 205 & 49 & 154 & 2 & 152 & 74.1 & $148.1 * * *$ \\
\hline Total & 1200 & 499 & 701 & 181 & 513 & 7 & 506 & 72.1 & $501.3^{* * *}$ \\
\hline
\end{tabular}

Note: The null hypothesis is that "Both individuals are treated unfavorably equally often", that is, (2)=(3). (***) Statistically significant at the $1 \%$ level. 
Table 5. Aggregate correspondence test results for more-informative applicants:

Heterosexual females vs. lesbians

\begin{tabular}{|c|c|c|c|c|c|c|c|c|c|}
\hline & \multirow{2}{*}{ Jobs } & \multirow{2}{*}{$\begin{array}{l}\text { Neither } \\
\text { Invited } \\
\text { No. }\end{array}$} & \multirow{2}{*}{$\begin{array}{l}\text { At } \\
\text { least } \\
\text { one } \\
\text { invited } \\
\\
\text { (1) } \\
\text { No. }\end{array}$} & \multirow{2}{*}{$\begin{array}{l}\text { Equal } \\
\text { Treatment }\end{array}$} & \multirow{2}{*}{$\begin{array}{l}\text { Only } \\
\text { heterosexual } \\
\text { females } \\
\text { invited } \\
\text { (2) } \\
\text { No. }\end{array}$} & \multirow{2}{*}{$\begin{array}{l}\text { Only lesbians } \\
\text { invited } \\
\text { (3) } \\
\text { No. }\end{array}$} & \multicolumn{2}{|c|}{ Net discrimination } & \multirow{2}{*}{$\begin{array}{l}\mathrm{x}^{2} \\
\text { test }\end{array}$} \\
\hline & & & & & & & $\begin{array}{l}(2)-(3) \\
\text { No. }\end{array}$ & $\begin{array}{c}(2)-(3) /(1) \\
\%\end{array}$ & \\
\hline Office Jobs & 274 & 97 & 177 & 35 & 141 & 1 & 140 & 79.0 & $138.0 * * *$ \\
\hline Industries & 258 & 89 & 169 & 39 & 129 & 1 & 128 & 75.3 & $126.0 * * *$ \\
\hline $\begin{array}{l}\text { Restaurant \& } \\
\text { Café Services }\end{array}$ & 172 & 91 & 81 & 14 & 64 & 3 & 61 & 75.3 & $55.5 * * *$ \\
\hline Shop Sales & 364 & 190 & 174 & 32 & 139 & 3 & 136 & 78.1 & $130.2 * * *$ \\
\hline Total & 1068 & 467 & 601 & 120 & 473 & 8 & 465 & 77.3 & $449.5 * * *$ \\
\hline
\end{tabular}

Note: The null hypothesis is that "Both individuals are treated unfavorably equally often", that is, (2)=(3). (***) Statistically significant at the $1 \%$ level. 
Table 6. Mean monthly wage offers $(€)$ for more-informative applicants:

Heterosexual males (females) vs. gay males (lesbians)

\begin{tabular}{|c|c|c|c|c|c|c|c|c|}
\hline & $\begin{array}{l}\text { Heterosexual } \\
\text { males }\end{array}$ & $\begin{array}{l}\text { Gay } \\
\text { males }\end{array}$ & $\begin{array}{l}\text { Raw } \\
\text { difference }\end{array}$ & $\begin{array}{l}\text { Difference } \\
\text { test } \\
\text { (t-test) }\end{array}$ & $\begin{array}{l}\text { Heterosexual } \\
\text { females }\end{array}$ & Lesbians & $\begin{array}{l}\text { Raw } \\
\text { difference }\end{array}$ & $\begin{array}{l}\text { Difference } \\
\text { test } \\
\text { (t-test) }\end{array}$ \\
\hline Office Jobs & 1315.4 (114) & $1191.1(17)$ & 124.3 & 4.0 *** & $1133.1(98)$ & $1093.3(15)$ & 39.8 & $2.3 * * *$ \\
\hline Industries & $1141.9(131)$ & $1051.7(41)$ & 90.2 & $3.8 * * *$ & $1106.2(119)$ & $1044.6(28)$ & 61.6 & $2.6 * * *$ \\
\hline $\begin{array}{l}\text { Restaurant \& } \\
\text { Café Services }\end{array}$ & $1122.1(121)$ & $1064.1(38)$ & 58 & $3.2 * * *$ & $1073.4(52)$ & $1027.2(10)$ & 46.2 & $2.4 * * *$ \\
\hline Shop Sales & $1121.4(127)$ & $1047.7(22)$ & 73.7 & $3.1 * * *$ & $1102.1(103)$ & $1021.5(19)$ & 80.6 & $3.0 * * *$ \\
\hline Total & $1168.0(493)$ & $1055.6(118)$ & 112.4 & $3.7 * * *$ & $1108.2(372)$ & $1038.8(72)$ & 92.2 & $2.8 * * *$ \\
\hline
\end{tabular}

Note: (***) Statistically significant at the 1\% level. The number of observations is in parentheses. 
Table 7. Occupational access estimations (Probit - marginal effects)

\begin{tabular}{|c|c|c|c|c|c|c|}
\hline & Panel I: Males & Panel II: Males & Panel III: Males & Panel IV :Females & Panel V :Females & Panel VI : Females \\
\hline & $\begin{array}{l}\text { Less- } \\
\text { informative } \\
\text { applicants }\end{array}$ & $\begin{array}{l}\text { More- } \\
\text { informative } \\
\text { applicants }\end{array}$ & $\begin{array}{l}\text { Total } \\
\text { Sample }\end{array}$ & $\begin{array}{l}\text { Less- } \\
\text { informative } \\
\text { applicants }\end{array}$ & $\begin{array}{l}\text { More- } \\
\text { informative } \\
\text { applicants }\end{array}$ & $\begin{array}{l}\text { Total } \\
\text { Sample }\end{array}$ \\
\hline Sexual & -0.389 & -0.392 & -0.390 & -0.424 & -0.434 & -0.427 \\
\hline orientation & $(0.017)^{* * *}$ & $(0.017)^{* * *}$ & $(0.012)^{* * *}$ & $(0.018)^{* * *}$ & $(0.026)^{* * *}$ & $(0.019)^{* * *}$ \\
\hline Cover letter's & 0.015 & 0.016 & 0.008 & -0.012 & 0.007 & -0.014 \\
\hline type & $(0.013)$ & $(0.014)$ & $(0.014)$ & $(0.014)$ & $(0.022)$ & $(0.013)$ \\
\hline Curriculum & -0.002 & -0.002 & 0.003 & 0.009 & -0.010 & 0.009 \\
\hline $\begin{array}{l}\text { vitae's } \\
\text { type }\end{array}$ & $(0.014)$ & $(0.022)$ & $(0.007)$ & $(0.010)$ & $(0.043)$ & $(0.014)$ \\
\hline Application's & -0.030 & -0.034 & 0.018 & 0.022 & 0.026 & 0.012 \\
\hline sending order & $(0.034)$ & $(0.053)$ & $(0.025)$ & $(0.017)$ & $(0.021)$ & $(0.011)$ \\
\hline Office & 0.037 & 0.029 & 0.026 & 0.033 & 0.041 & 0.036 \\
\hline jobs & $(0.029)$ & $(0.025)$ & $(0.022)$ & $(0.028)$ & $(0.027)$ & $(0.027)$ \\
\hline Industrial & 0.039 & 0.037 & 0.020 & 0.038 & 0.030 & 0.032 \\
\hline jobs & $(0.029)$ & $(0.028)$ & $(0.014)$ & $(0.026)$ & $(0.020)$ & $(0.023)$ \\
\hline Restaurant & 0.036 & 0.039 & 0.027 & 0.030 & 0.037 & 0.042 \\
\hline $\begin{array}{l}\text { and café } \\
\text { services }\end{array}$ & $(0.028)$ & $(0.029)$ & $(0.020)$ & $(0.027)$ & $(0.025)$ & $(0.032)$ \\
\hline $\begin{array}{l}\text { Sexual } \\
\text { orientation } \mathrm{x} \\
\text { office jobs }\end{array}$ & $\begin{array}{l}-0.005 \\
(0.001)^{* * *}\end{array}$ & $\begin{array}{l}-0.002 \\
(0.001)^{* * *}\end{array}$ & $\begin{array}{l}-0.008 \\
(0.002)^{* * *}\end{array}$ & $\begin{array}{l}-0.004 \\
(0.001)^{* * *}\end{array}$ & $\begin{array}{l}-0.003 \\
(0.001)^{* * *}\end{array}$ & $\begin{array}{l}-0.004 \\
(0.001)^{* * *}\end{array}$ \\
\hline $\begin{array}{l}\text { Sexual } \\
\text { orientation } \mathrm{x} \\
\text { industrial jobs }\end{array}$ & $\begin{array}{l}-0.004 \\
(0.001)^{* * *}\end{array}$ & $\begin{array}{l}-0.003 \\
(0.001)^{* * *}\end{array}$ & $\begin{array}{l}-0.005 \\
(0.002)^{* * *}\end{array}$ & $\begin{array}{l}-0.003 \\
(0.001)^{* * *}\end{array}$ & $\begin{array}{l}-0.002 \\
(0.001)^{* * *}\end{array}$ & $\begin{array}{l}-0.003 \\
(0.001)^{* * *}\end{array}$ \\
\hline $\begin{array}{l}\text { Sexual } \\
\text { orientation } \mathrm{x} \\
\text { restaurant and } \\
\text { café services }\end{array}$ & $\begin{array}{l}-0.003 \\
(0.001)^{* * *}\end{array}$ & $\begin{array}{l}-0.005 \\
(0.001)^{* * *}\end{array}$ & $\begin{array}{l}-0.005 \\
(0.001)^{* * *}\end{array}$ & $\begin{array}{l}-0.003 \\
(0.001)^{* * *}\end{array}$ & $\begin{array}{l}-0.003 \\
(0.001)^{* * *}\end{array}$ & $\begin{array}{l}-0.003 \\
(0.001)^{* * *}\end{array}$ \\
\hline $\begin{array}{l}\text { More- } \\
\text { informative } \\
\text { applicants }\end{array}$ & - & - & $\begin{array}{l}0.035 \\
(0.014)^{* * *}\end{array}$ & - & - & $\begin{array}{l}0.051 \\
(0.018) * * *\end{array}$ \\
\hline $\begin{array}{l}\text { Sexual } \\
\text { orientation } \mathrm{x} \\
\text { more- } \\
\text { informative } \\
\text { applicants }\end{array}$ & - & - & $\begin{array}{l}-0.019 \\
(0.028)\end{array}$ & - & - & $\begin{array}{l}-0.034 \\
(0.029)\end{array}$ \\
\hline $\begin{array}{l}\text { Letter of } \\
\text { reference's } \\
\text { type }\end{array}$ & - & $\begin{array}{l}0.172 \\
(0.120)\end{array}$ & - & - & $\begin{array}{l}0.168 \\
(0.133)\end{array}$ & - \\
\hline City effects & Yes & Yes & Yes & Yes & Yes & Yes \\
\hline Time effects & Yes & Yes & Yes & Yes & Yes & Yes \\
\hline Pseudo $\mathrm{R}^{2}$ & 0.053 & 0.044 & 0.062 & 0.057 & 0.052 & 0.066 \\
\hline Observations & 2,446 & 2,400 & 4,846 & 2,080 & 2,136 & 4,216 \\
\hline
\end{tabular}

Note: Each column is a separate regression. (***) Statistically significant at the $1 \%$ level. Standard errors adjusted for clustering are in parentheses. 
Table 8. Wage (natural logs) Estimations (OLS)

\begin{tabular}{|c|c|c|c|c|c|c|}
\hline & $\begin{array}{l}\text { Panel I: } \\
\text { Males } \\
\text { Less- } \\
\text { informative } \\
\text { applicants }\end{array}$ & $\begin{array}{l}\text { Panel II: } \\
\text { Males } \\
\text { More- } \\
\text { informative } \\
\text { applicants }\end{array}$ & $\begin{array}{l}\text { Panel III: } \\
\text { Males } \\
\text { Total } \\
\text { Sample }\end{array}$ & $\begin{array}{l}\text { Less- } \\
\text { informative } \\
\text { applicants }\end{array}$ & $\begin{array}{l}\text { Panel V :Females } \\
\text { More- } \\
\text { informative } \\
\text { applicants }\end{array}$ & $\begin{array}{l}\text { Panel VI : Females } \\
\text { Total } \\
\text { Sample }\end{array}$ \\
\hline $\begin{array}{l}\text { Sexual } \\
\text { orientation } \\
\text { Cover letter's type }\end{array}$ & $\begin{array}{l}-0.090 \\
(0.011)^{* * *} \\
-0.008 \\
(0.008)\end{array}$ & $\begin{array}{l}-0.095 \\
(0.019) * * * \\
-0.005 \\
(0.007)\end{array}$ & $\begin{array}{l}-0.092 \\
(0.015)^{* * *} \\
0.008 \\
(0.011)\end{array}$ & $\begin{array}{l}-0.056 \\
(0.011) * * * \\
0.004 \\
(0.007)\end{array}$ & $\begin{array}{l}-0.059 \\
(0.013) * * * \\
-0.006 \\
(0.005)\end{array}$ & $\begin{array}{l}-0.058 \\
(0.012) * * * \\
0.010 \\
(0.009)\end{array}$ \\
\hline $\begin{array}{l}\text { Curriculum } \\
\text { vitae's type }\end{array}$ & $\begin{array}{l}0.014 \\
(0.013)\end{array}$ & $\begin{array}{l}0.009 \\
(0.010)\end{array}$ & $\begin{array}{l}0.011 \\
(0.010)\end{array}$ & $\begin{array}{l}0.007 \\
(0.009)\end{array}$ & $\begin{array}{l}-0.003 \\
(0.004)\end{array}$ & $\begin{array}{l}-0.009 \\
(0.009)\end{array}$ \\
\hline $\begin{array}{l}\text { Application's } \\
\text { sending order }\end{array}$ & $\begin{array}{l}0.009 \\
(0.016)\end{array}$ & $\begin{array}{l}0.010 \\
(0.012)\end{array}$ & $\begin{array}{l}0.010 \\
(0.009)\end{array}$ & $\begin{array}{l}-0.007 \\
(0.008)\end{array}$ & $\begin{array}{l}0.012 \\
(0.009)\end{array}$ & $\begin{array}{l}0.006 \\
(0.007)\end{array}$ \\
\hline Office jobs & $\begin{array}{l}0.046 \\
(0.036)\end{array}$ & $\begin{array}{l}0.051 \\
(0.064)\end{array}$ & $\begin{array}{l}0.048 \\
(0.029)\end{array}$ & $\begin{array}{l}0.033 \\
(0.020)\end{array}$ & $\begin{array}{l}0.041 \\
(0.029)\end{array}$ & $\begin{array}{l}0.037 \\
(0.026)\end{array}$ \\
\hline $\begin{array}{l}\text { Industrial } \\
\text { jobs }\end{array}$ & $\begin{array}{l}0.041 \\
(0.021)^{* *}\end{array}$ & $\begin{array}{l}0.043 \\
(0.028)\end{array}$ & $\begin{array}{l}0.041 \\
(0.034)\end{array}$ & $\begin{array}{l}0.040 \\
(0.029)\end{array}$ & $\begin{array}{l}0.042 \\
(0.029)\end{array}$ & $\begin{array}{l}0.040 \\
(0.039)\end{array}$ \\
\hline $\begin{array}{l}\text { Restaurant and } \\
\text { café services }\end{array}$ & $\begin{array}{l}0.050 \\
(0.037)\end{array}$ & $\begin{array}{l}0.053 \\
(0.029)\end{array}$ & $\begin{array}{l}0.050 \\
(0.068)\end{array}$ & $\begin{array}{l}0.042 \\
(0.026)\end{array}$ & $\begin{array}{l}0.046 \\
(0.028)\end{array}$ & $\begin{array}{l}0.043 \\
(0.064)\end{array}$ \\
\hline $\begin{array}{l}\text { Sexual orientation } \\
\mathrm{x} \text { office jobs }\end{array}$ & $\begin{array}{l}-0.023 \\
(0.005)^{* * *}\end{array}$ & $\begin{array}{l}-0.025 \\
(0.004)^{* * *}\end{array}$ & $\begin{array}{l}-0.023 \\
(0.004)^{* * *}\end{array}$ & $\begin{array}{l}-0.018 \\
(0.006) * * *\end{array}$ & $\begin{array}{l}-0.020 \\
(0.005)^{* * *}\end{array}$ & $\begin{array}{l}-0.020 \\
(0.005) * * *\end{array}$ \\
\hline $\begin{array}{l}\text { Sexual orientation } \\
\mathrm{x} \text { industrial jobs }\end{array}$ & $\begin{array}{l}-0.021 \\
(0.003) * * *\end{array}$ & $\begin{array}{l}-0.022 \\
(0.004)^{* * *}\end{array}$ & $\begin{array}{l}-0.021 \\
(0.010) * * *\end{array}$ & $\begin{array}{l}-0.015 \\
(0.005)^{* * *}\end{array}$ & $\begin{array}{l}-0.018 \\
(0.005)^{* * *}\end{array}$ & $\begin{array}{l}-0.018 \\
(0.004)^{* * *}\end{array}$ \\
\hline $\begin{array}{l}\text { Sexua lorientation } \\
\mathrm{x} \text { restaurant and } \\
\text { café services }\end{array}$ & $\begin{array}{l}-0.020 \\
(0.007) * * *\end{array}$ & $\begin{array}{l}-0.025 \\
(0.006)^{* * *}\end{array}$ & $\begin{array}{l}-0.023 \\
(0.005)^{* * *}\end{array}$ & $\begin{array}{l}-0.017 \\
(0.006)^{* * *}\end{array}$ & $\begin{array}{l}-0.019 \\
(0.006)^{* * *}\end{array}$ & $\begin{array}{l}-0.017 \\
(0.007)^{* * *}\end{array}$ \\
\hline Call back order & $\begin{array}{l}0.011 \\
(0.009)\end{array}$ & $\begin{array}{l}-0.007 \\
(0.012)\end{array}$ & $\begin{array}{l}-0.011 \\
(0.010)\end{array}$ & $\begin{array}{l}-0.009 \\
(0.009)\end{array}$ & $\begin{array}{l}0.010 \\
(0.008)\end{array}$ & $\begin{array}{l}0.013 \\
(0.011)\end{array}$ \\
\hline Employers' sex & $\begin{array}{l}0.024 \\
(0.016)\end{array}$ & $\begin{array}{l}-0.043 \\
(0.029)\end{array}$ & $\begin{array}{l}0.031 \\
(0.021)\end{array}$ & $\begin{array}{l}0.025 \\
(0.022)\end{array}$ & $\begin{array}{l}0.027 \\
(0.019)\end{array}$ & $\begin{array}{l}0.041 \\
(0.034)\end{array}$ \\
\hline $\begin{array}{l}\text { Sexual orientation } \\
\text { x employers' sex }\end{array}$ & $\begin{array}{l}-0.024 \\
(0.015)\end{array}$ & $\begin{array}{l}-0.031 \\
(0.026)\end{array}$ & $\begin{array}{l}-0.037 \\
(0.029)\end{array}$ & $\begin{array}{l}0.015 \\
(0.011)\end{array}$ & $\begin{array}{l}-0.019 \\
(0.016)\end{array}$ & $\begin{array}{l}-0.016 \\
(0.014)\end{array}$ \\
\hline $\begin{array}{l}\text { More-informative } \\
\text { applicants }\end{array}$ & - & - & $\begin{array}{l}0.015 \\
(0.009)^{*}\end{array}$ & - & - & $\begin{array}{l}0.021 \\
(0.006) * * *\end{array}$ \\
\hline $\begin{array}{l}\text { Sexual orientation } \\
\mathrm{x} \text { more } \\
\text { informative } \\
\text { applicants }\end{array}$ & - & - & $\begin{array}{l}0.001 \\
(0.011)\end{array}$ & - & - & $\begin{array}{l}-0.001 \\
(0.016)\end{array}$ \\
\hline $\begin{array}{l}\text { Letter of } \\
\text { reference's type }\end{array}$ & - & $\begin{array}{l}0.012 \\
(0.011)\end{array}$ & - & - & $\begin{array}{l}0.016 \\
(0.013)\end{array}$ & - \\
\hline Tester effects & Yes & Yes & Yes & Yes & Yes & Yes \\
\hline City effects & Yes & Yes & Yes & Yes & Yes & Yes \\
\hline Time effects & Yes & Yes & Yes & Yes & Yes & Yes \\
\hline Adj. $\mathrm{R}^{2}$ & 0.315 & 0.370 & 0.365 & 0.266 & 0.310 & 0.324 \\
\hline Observations & 500 & 611 & 1,111 & 368 & 444 & 812 \\
\hline
\end{tabular}

Note: Each column is a separate regression. (*) Statistically significant at the $10 \%$ level. (**) Statistically significant at the 5\% level. (***) Statistically significant at the $1 \%$ level. Standard errors adjusted for clustering are in parentheses. 
Appendix A: Curriculum Vitae. Less-informative applicants - short versions

\begin{tabular}{|c|c|}
\hline Sexual orientation majority (Type A) & Sexual orientation minority (Type B) \\
\hline $\begin{array}{l}\text { Cover Letter } \\
\text { Dear Sir/Madam, } \\
\text { Please find attached my Curriculum Vitae for your } \\
\text { kind consideration for the vacancy as was } \\
\text { advertised in.... } \\
\text { Yours sincerely, } \\
\text { Name and surname } \\
\text { Curriculum Vitae } \\
\text { First Name: } \\
\text { Last Name: } \\
\text { Ethnicity: Greek Cypriot } \\
\text { Marital Status: Unmarried } \\
\text { Date of Birth: ......./1980 } \\
\text { Address: Location } \\
\text { Telephone: Mobile } \\
\text { Education: } \\
\text { High School diploma in } 1998, \text { Location } \\
\text { Basic Knowledge of English and P/C } \\
\text { Driving license } \\
\text { Professional Experience: } \\
\text { From } 2000 \text { to } 2004 \\
\text { Job task / Firm } \\
\text { From } 2004 \text { to } 2007 \\
\text { Job task / Firm } \\
\text { From } 2007 \text { to ... } 2010 / 2011 \\
\text { Job task / Firm } \\
\text { Interests: } \\
\text { Cinema, Music } \\
\text { Volunteer in the Nature: Environmental Union } \\
\text { from } 2005-2008\end{array}$ & $\begin{array}{l}\text { Cover Letter } \\
\text { Dear Sir/Madam, } \\
\text { Please consider my application for the vacancy as } \\
\text { was advertised in.... I attach my Curriculum Vitae. } \\
\text { Yours faithfully, } \\
\text { Name and surname } \\
\text { Curriculum Vitae } \\
\text { First Name } \\
\text { Last Name } \\
\text { Date of Birth ......./1980 } \\
\text { Ethnicity Greek Cypriot } \\
\text { Marital Status Unmarried } \\
\text { Address Location } \\
\text { Telephone Mobile } \\
\text { Experience } \\
\text { Firm / Job task } \\
\text { 2000 -2003 } \\
\text { Firm / Job } \\
\text { 2003 - 2008 } \\
\text { Firm / Job task } \\
2008 \text { - ... 2010/2011 } \\
\text { Education } \\
\text { High School diploma in 1998, Location } \\
\text { English Basic Knowledge } \\
\text { P/C Basic Knowledge } \\
\text { Driving license } \\
\text { Interests } \\
\text { Music and cinema } \\
\text { Member-volunteer in the Cypriot Homosexual } \\
\text { Association (05-08) }\end{array}$ \\
\hline
\end{tabular}


Appendix B: Curriculum vitae. More-informative applicants - short versions

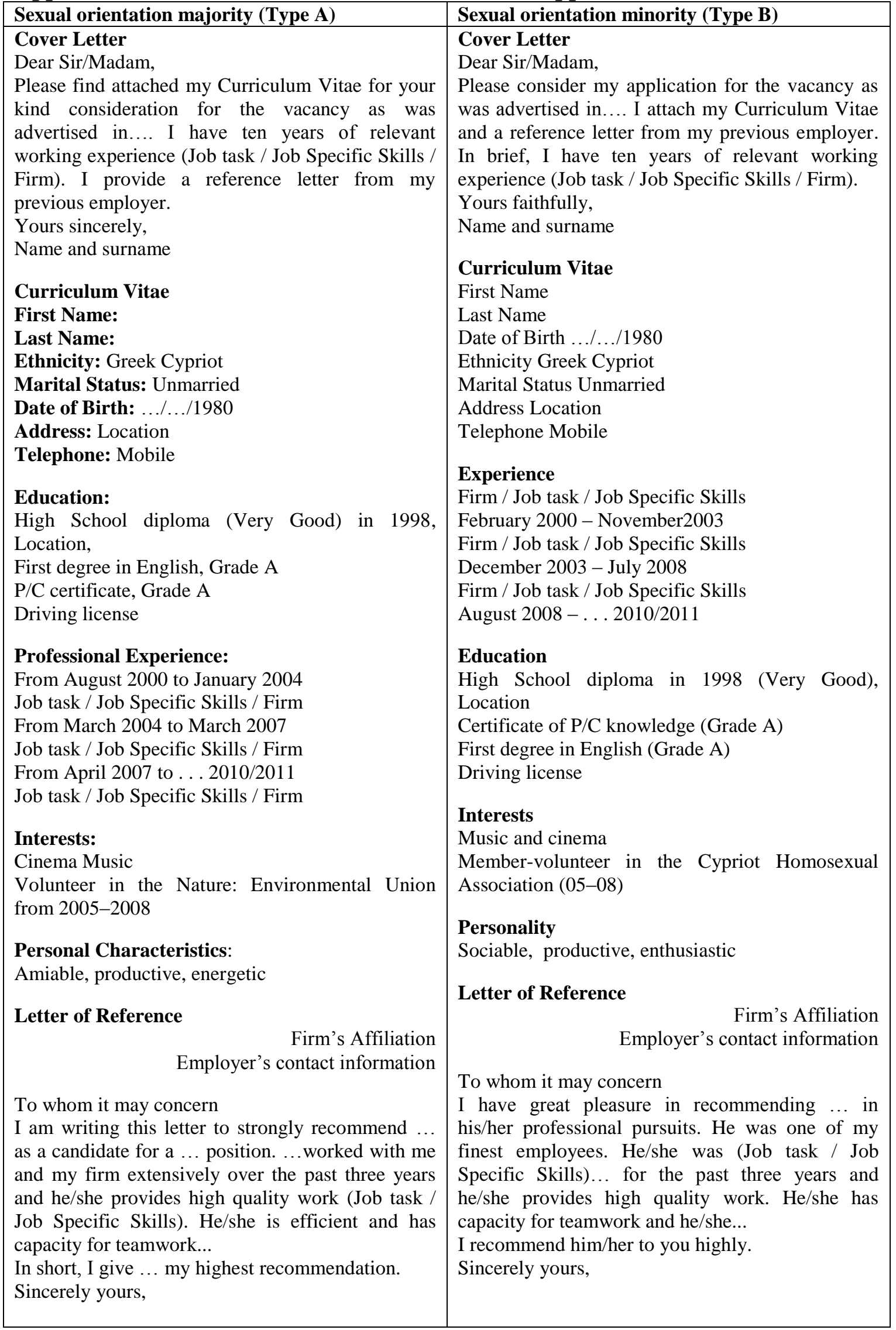




\section{Appendix C: Matched pair of applicants and randomized information}

\begin{tabular}{|c|c|}
\hline $\begin{array}{l}\text { Matched pair 1: } \\
\text { Heterosexual males vs gay males } \\
\text { with low informative applications }\end{array}$ & $\begin{array}{l}\text { Matched pair 2: } \\
\text { Heterosexual males vs gay males } \\
\text { with more informative applications }\end{array}$ \\
\hline Standard information* & $\begin{array}{l}\text { Standard information* } \\
+ \text { grading scales } \\
+ \text { personality traits } \\
\text { + information regarding previous job tasks } \\
\text { + letters of reference }\end{array}$ \\
\hline $\begin{array}{l}\text { Matched pair 3: } \\
\text { Heterosexual females vs lesbians } \\
\text { with low informative applications }\end{array}$ & $\begin{array}{l}\text { Matched pair 4: } \\
\text { Heterosexual females vs lesbians } \\
\text { with more informative applications }\end{array}$ \\
\hline Standard information* & $\begin{array}{l}\text { Standard information* } \\
+ \text { grading scales } \\
+ \text { personality traits } \\
+ \text { information regarding previous job tasks } \\
+ \text { letters of reference }\end{array}$ \\
\hline
\end{tabular}

Notes: Standard information includes: Greek Cypriot names, mobile telephone number, postal address, age, ethnicity, marital status, school level, job experience, basic knowledge of English and $P / C$, and hobbies. 


\section{Appendix D: List of variables}

\begin{tabular}{|c|c|}
\hline Name & Definition \\
\hline Callback & $=1$ if the applicant receives an appointment,$=0$ if not \\
\hline $\begin{array}{l}\text { Monthly wage } \\
\text { offers (natural } \\
\text { log) }\end{array}$ & $=$ monthly wages offered (natural log) by employers \\
\hline Sexual orientation & $=1$ if the applicant is labeled as being gay male/lesbian, $=0$ if not \\
\hline $\begin{array}{l}\text { Application's } \\
\text { sending order }\end{array}$ & $=1$ if the gay males'/lesbian's CV is sent first, $=0$ if not \\
\hline $\begin{array}{l}\text { Curriculum } \\
\text { vitae's type }\end{array}$ & $=1$ if the $\mathrm{CV}$ is of type $\mathrm{A},=0$ if not \\
\hline $\begin{array}{l}\text { Cover letter's } \\
\text { type }\end{array}$ & $=1$ if the Cover Letter is of type $\mathrm{A},=0$ if not \\
\hline $\begin{array}{l}\text { Letters of } \\
\text { reference's type }\end{array}$ & $=1$ if the letters of reference is of type $\mathrm{A},=0$ if not \\
\hline Office jobs & $=1$ if the applicant applied for a vacancy in office jobs, $=0$ if not \\
\hline Industrial jobs & $=1$ if the applicant applied for a vacancy in industrial jobs,$=0$ if not \\
\hline $\begin{array}{l}\text { Restaurant and } \\
\text { café services }\end{array}$ & $=1$ if the applicant applied for a vacancy in restaurant and café services, $=0$ if not \\
\hline $\begin{array}{l}\text { More informative } \\
\text { applicant }\end{array}$ & $=1$ if the application belongs to the more-informative applicant,$=0$ if not \\
\hline Callback order & $=1$ if the employer callbacks the gay male/lesbian applicant first, $=0$ if not \\
\hline $\begin{array}{l}\text { Employers' } \\
\text { gender }\end{array}$ & $=1$ if the employer is male, $=0$ if not \\
\hline Tester's impact & $\begin{array}{l}=1 \text { for tester No. } 1,=0 \text { if not } \\
=1 \text { for tester No. } 2,=0 \text { if not } \\
=1 \text { for tester No. } 3,=0 \text { if not }\end{array}$ \\
\hline City effects & $\begin{array}{l}=1 \text { if the applicant applied for a vacancy in Nicosia, }=0 \text { if not } \\
=1 \text { if the applicant applied for a vacancy in Limassol, }=0 \text { if not } \\
=1 \text { if the applicant applied for a vacancy in Larnaca, }=0 \text { if not }\end{array}$ \\
\hline Time effects & $\begin{array}{l}=1 \text { if the application is sent in January } 2010,=0 \text { if not } \\
=1 \text { if the application is sent in February 2010, =0 if not } \\
=1 \text { if the application is sent in March 2010, =0 if not } \\
=1 \text { if the application is sent in April 2010, =0 if not } \\
=1 \text { if the application is sent in May 2010, =0 if not } \\
=1 \text { if the application is sent in June 2010, =0 if not } \\
=1 \text { if the application is sent in July 2010, =0 if not } \\
=1 \text { if the application is sent in August } 2010,=0 \text { if not } \\
=1 \text { if the application is sent in September } 2010,=0 \text { if not } \\
=1 \text { if the application is sent in October } 2010,=0 \text { if not } \\
=1 \text { if the application is sent in November } 2010,=0 \text { if not } \\
=1 \text { if the application is sent in December } 2010,=0 \text { if not }\end{array}$ \\
\hline
\end{tabular}

